\title{
Right to Own Land by the State in the Frame of Constitutional Law
}

DOI: https://doi.org/10.47175/rissj.v2i2.214

\section{| Zainuddin |}

Faculty of Law, Universitas Muhammadiyah Sumatera Utara, Indonesia

zainuddin@umsu.ac.id

\begin{abstract}
The right to control the state over land should be able to achieve the greatest prosperity of the people as mandated by Article 33 paragraph (3) of the 1945 Constitution of the Unitary State of the Republic of Indonesia. It is important to discuss the problem of the meaning of the substance of the right to control land by the State based on the 1945 Constitution. and what is the right to control land by the state based on regulations in the framework of constitutional law so that land for the greatest prosperity of the people can be achieved. The research method used is the normative juridical legal research method. The results show that the right to control land by the state within the framework of constitutional law is still very far from being burned, so that the prosperity of the people, one of which can be achieved through proper management of land controlled by the state, has not been able to achieve people's happiness as adhered to by the theory of utilitarianism law and more. continued as stated in the 1945 Constitution and the Basic Agrarian Law applicable in Indonesia. KEYWORDS

land cases; regulation; law; state
\end{abstract}

\section{INTRODUCTION}

Land cases are a problem that has emerged and developed in Indonesia. Various land disputes and land disputes occur in the community. One of the problems related to agrarian resources in Indonesia is the emergence of social conflicts in society. Various conflicts involving the masses then emerged in conflicts with the government and private sector operating in the agrarian realm (Zakie, 2017).

This happens due to the fact that community life requires the existence and availability of land. Tristanto stated that "So important is the function of land for the community, it needs to be regulated in order to guarantee its control and utilization as well as to create legal certainty for the community. The problem that has arisen since the independence period was disproportionate ownership of land. In order to overcome this problem, the government has passed Law Number 5 Year 1960 Concerning Agrarian Principles" (Tristanto, 2019).

In the Decree of the People's Consultative Assembly (TAP MPR) Number: IX / MPR / 2001 concerning Agrarian Reform and Natural Resources Management, it is emphasized that "there is a need for agrarian reform and natural resource management based on the principles of national unity, rule of law, democracy, justice., respecting customary law rights, the balance of rights and obligations between the state, the government and the people. This mandate can basically be interpreted as a review of all policies on natural resources, especially land, which have been occurring both in terms of political law, laws and regulations as well as their implementation" (Erwiningsih, 2009). 
This is written in the formulation of Article 33 paragraph (3) of the 1945 Constitution which states that: "The land and water and natural resources contained therein are controlled by the state and used for the greatest prosperity of the people". The embodiment of the mandate of the constitution has been assigned in Law Number 5 of 1960 concerning Basic Agrarian Basic Regulations (UUPA) which are subsequently used as the main regulations in determining the basis for the political direction of national agrarian law policies, especially related to human relations with land along with all rights. and its obligations.

Because in fact the definition of agrarian according to the UUPA is not only limited to land, but also includes earth, water and natural resources including space. Boedi Harsono explained that "space is one of the national agrarian resources because on earth and water contain energy and elements that can be used for efforts to maintain and develop earth fertility, water and natural resources and other related matters. with that " (Harsono, 2007).

Moving on from the above definition, the philosophical basis for managing natural / agrarian resources as joint ownership of the Indonesian nation concerns the control, ownership and use of agrarian resources to be used "for the greatest prosperity of the people", in accordance with Article 3 of the 1945 Constitution. it is justice for the people for the management of agrarian resources, especially land issues. In practice, the management of agrarian and natural resources, especially land, cannot be separated from different interests. This is in line with the increase in the human population figure which is inversely proportional to the static land availability rate which is tense. The interests that arise in the problem of agrarian and natural resource management are considered as social phenomena which illustrate that the law is considered as the result of the development of the Historical Society where the law is located, where the contents of the law are located. determined by the development of community customs throughout history; the content of rights is determined by the history of the society in which they apply (Limbong, 2012).

This is proven by the formation of Indonesia's national agrarian law which is summarized in positive law in the form of UUPA. Judging from its history, the contents of the LoGA as a system adheres to the Western Agrarian Law system, the Feudal System and the Customary Law System (Limbong, 2012). This is the reason for the push to reform the national agrarian law, which has been discussed for a long time. This urge is targeted at the direction of the arrangement of various interests on the management of agaraia and natural resources as mentioned above, especially land.

The focus of the study in this research is focused on the meaning of the right to control land by the state from the juridical side which is contained in various national land law regulations. Especially in the context of the authority to regulate, manage and supervise the control of land rights. The aim is to see the position of land rights by the state based on a strict legal framework through positive legal regulations in effect in Indonesia. The focus of this study is an option based on the fact that land is a determinant factor in the creation of community welfare (Soejono, 1998), even though in its implementation, land problems have not failed to cause political, legal, social and economic problems.

\section{RESEARCH METHODS}

This study uses a normative juridical research method. This means that the research is carried out by conducting a literature study. The discussion is based on various literatures in the form; books, documents and statutory regulations as well as references relating to the Right to Own Land by the State. Cohen quoted by Marzuki said "in legal research there are several approaches used, namely: statutory approach, conceptual approach, analytical approach, comparative approach" hysterical approach, philosophical approach, case 
approach (Ramadhani, 2017). The problem approach is to make an approach with the results of empirical theoretical study by looking at differences in opinion of experts, writers and studies of laws and regulations relating to the issue of land tenure rights by the state.

\section{RESULTS AND DISCUSSION}

\section{The meaning and substance of the state's right to control over land according to the 1945 Constitution.}

Earth and soil as inseparable elements are an important part of human life. For cosmologists, the earth is a human being from the place where they live, where they work and live, where they come from and where they go. In this sense, land has economic, social, cultural, political and ecological dimensions (Zakie, 2017). The increased use of land has resulted in a diversity of patterns and forms of the relationship between humans and the earth, which at the same time leads to the emergence of development in the field of normative land law, both in written and unwritten law. Developments that affect the company's vision in the field, both in terms of ownership, governance and use (Zakie, 2017).

In essence, land has two simultaneous functions, namely production and non-production functions. The need for land use often collides, because with the existence of a large limited amount of land, on the other hand there is a population explosion. This condition is considered to be one of the factors triggering the skyrocketing number of disputes, conflicts and land ownership cases in Indonesia (Ramadhani, 2019).

Land can be interpreted as economic value, while area is defined as non-economic benefits. Historically, past land conflicts have proven that the emergence of conflicts and bloodshed in the past to the war in Iraq and all wars on earth were caused by the struggle for control of land territory (Zakie, 2017).

A Western scholar compares the earth to a diamond or gemstone which has many aspects, and sometimes the earth is viewed as space, nature, factors of production, consumption of goods, property and capital. In addition, there are also those who view the earth as something related to the Creator (God), associated with society which leads to the view that the earth is like the universe, and the view that the earth is like a savior (savior) and makes land an asset/wealth (Barlowe, 1978).

The various relationships between humans and society as a structure are also influenced by the earth as an element that gives color to human life. Thus, land takes a dominant share in human life (B. Ter Haar, Bzn, Terjemahan Schiller, 1962). Land ownership in Indonesia is also known for the existence of customary rules, as a society that has a very rich culture, Indonesia still adheres to these rules, although the format of customary law is not in written form but rather unwritten (Hermayulis, 1999).

Indonesia adalah negara hukum, sebagaimana secara jelas tertuang dalam konstitusi, yang pada hakikatnya mempunyai hakikat bahwa Indonesia adalah negara yang menganut teori negara hukum (Rechts-souvereiniteit), bukan berdasarkan kekuasaan murni (Machtsstaat) dan pemerintahannya pada Landasan sistem ketatanegaraan (Basic Law), tidak mutlak/kekuasaan tidak terbatas. Krabbe mengemukakan teori negara hukum (Rechts-souvereiniteit), dimana otoritas tertinggi di suatu negara adalah hukum itu sendiri. Karena penguasa yang baik, rakyat, bahkan miliknya sendiri, semua taat dan taat pada hukum. Semua sikap, tingkah laku bahkan kebijakan yang akan diambil harus sesuai dengan hukum (Soehino, 1998).

In the fourth paragraph of the Preamble to the 1945 Constitution of the Unitary State of the Republic of Indonesia (UUD 1945), it is stated that: "The state is founded on an 
almighty godhead in accordance with the fundamental human rights that are just and civilized within the framework of the State law. Republic of Indonesia ". In the paragraph that contains the point of view that:

Moral norms according to which humans must be fair in order to live their lives according to their dignity, only by maintaining a balance between rights and obligations. It is a principle that can be assumed that God gave humans the right to live with grace, so that God wants humans to carry out their duties according to God's wishes (Erwiningsih, 2009). The above conception is a common law principle that functions to bridge the human person, society, state and the environment in general.

Land law emerged as a response to human interest in land. The law limits land ownership. The parameters of the earth cannot be separated in a purely personal / individual relationship, but the Earth is the dome of the state. Land has become a source of prosperity for a nation, and when we talk about the nation, the state is actively involved in the management and utilization of the land. Article 33 paragraph (3) of the 1945 Constitution becomes the legal basis for control of natural resources, one of which is in the field. This is the basic concept of state control over land that aims to achieve a level of prosperity for the Indonesian people. However, on the plains, in execution, many of them are especially struggling in the field.

Article 33 paragraph 3 of the 1945 Constitution states: "Land, water and natural resources they contain shall be controlled by the state and used for the greatest prosperity of the people". So it also means that land and water as well as natural resources contained in the land are the main points of the people's prosperity. Therefore, it must be controlled by the state and used for the greatest prosperity of the people. From the description of Article 33 paragraph (3) of the 1945 Constitution emerges the right to control the state which indicates the existence of state authority to regulate the use of land as capital development. basic, as well as an important factor in people's lives which generally depend on their lives (Ramadhani, 2018).

Furthermore, the state is defined as an organization in an area that has the highest legal authority and is obeyed by its people, where power is the ability of a person or group to influence the behavior of a society. person or group, according to the wishes of the participants (Miriam Budiarjo, 2012).

Meanwhile, to see the definition of law, many experts interpret it, this shows that it is true that there is a law that is difficult to define. However, in general, law can be interpreted as a set of rules made by the authorities with the aim of regulating the lives of people who have rules and prohibitions as well as the characteristics of power by imposing sanctions on those who violate them (Soeroso, 1996).

In accordance with its definition, law is often seen as a tool of power, where the legislative and executive powers as legislators often penetrate politics into law through articles contained in the legislative regulations of the institution. In addition, it is understandable that the dynamics of legal regulations must continue to develop in line with the dynamics of community life, especially indigenous peoples (Hidayah \& Rahadiyan, 2018).

If we look at the definition of the state and law as explained above and regarding the right to govern the country according to the 1945 Constitution, it can be seen in the context of the people's welfare. The state's position as the ruling body of leadership is an ideological manifestation of the model of individual and community relations in the concept of customary law which crystallizes the values formulated in the preamble to the 1945 Constitution, so that it includes the right to control the state in the implementation of rights and obligations that give rise to power or authority or even authority. 
Thus, the concept of state control is power owned by the state which contains the authority, regulation, planning, administration / patronage, as well as supervision over the management, use and use of land at that time. Both in the relationship between individuals, society and the state with land as well as in the relationship between individuals and society (Erwiningsih, 2009).

From the definition above, it can be seen that there are powers and obligations for the state to carry out its duties. Franz Magnes Soncino distinguishes two types of authority, namely: authority in the sense that no authority has the right to demand obedience, therefore there is the right to give orders (deontes) which means that it must, as well as authority in the so-called science (epsytimes) (Erwiningsih, 2009).

The authority of the state to regulate, manage and supervise land rights, both individually, in society and as a state, is closely related to the concept of balance between the elements of rights and obligations contained therein, as well as obligations. On the contrary, each of the rights is included. Therefore, on the basis of rights, all individuals, communities and nations basically increase the prosperity and welfare of society and protect and guarantee all people's rights in the field, land for the truth. You are obliged to use and prevent any actions that have the potential to cause loss of land rights in the community (Erwiningsih, 2009)

Furthermore, the formation of statutory regulations as a manifestation of the power and authority of the state in terms of the Legislative and Executive is separated from political nuances. So that the legal rules produced by the material state often have political nuances, so it is very natural when a statement appears that "law is a political product" even though this statement invites controversy, because from the statement it seems that law is positioned as a social subsystem determined by politics. (M.D, 2011).

It is believed that the basic structure of the landbending relationship between individuals, society and the state above is the foundation that will lead the Indonesian nation to its glory in the future. Therefore, the state as an organization of national power and its position as a ruling body in carrying out an established function, maintaining and supervising contains substance, namely its realization. of the greatest prosperity of the people. Without strength; country, so it's impossible to; ensuring the well-being of the community associated with the land. However, state authority must also be exercised in accordance with the principles contained in the basic idea of the preamble to the 1945 Constitution, the constitution, and the prevailing laws and regulations for the treatment of the nation's position. During his reign, the state did not only have legal legitimacy but was also in accordance with the expected stages of welfare development.

\section{Right to Own Land by the State in the Frame of Constitutional Law}

History when Indonesian President Soekarno enacted Law Number 5 of 1960 concerning land reform and during the reform period that was formed. TAP MPR IX / MPR / 2001 regarding land reform and natural resource management. The problem that has existed in Indonesia since independence is land ownership, and the need for agricultural land is increasing along with the rapid population growth (Tristanto, 2019).

Supomo looked at that (Yamin, 1971): By the nature and ideals of unity of life, namely kawulo-gusti union, the outer world and the inner world, the macro cosmos and micro cosmos, between humans and their leaders; balance of soul, because the human person, group or community has a place in social life and the obligations of life (zarma which is owned according to natural and natural laws) of life are interrelated and influence each other. 
With regard to the right to control over land as referred to in Article 33 paragraph (3) of the 1945 Constitution above, as set forth in a series of laws and regulations that intend to become national agrarian rights encapsulated in the right to agriculture (UUPA) number 5 of 1960. UUPA is transformed as a form of law that emphasizes its usefulness on the basic structure of control and utilization of National Agrarian Affairs in Indonesia, especially those relating to land.

The introduction of the UUPA was not only as a substitute for the 1980 agricultural law, but also as a complete overhaul of the Dutch colonial legal inheritance system. There are 3 principles that are promoted, namely (Ahmad Nashih Luthfi, 2010): changing the colonial era agricultural system into a national agricultural system, in accordance with the interests of the state and the Indonesian people, and in particular the Indonesian peasants, to end dualism and lay the foundation for the unity and simplicity of state law, which is primarily based on common law, and provide legal certainty to the community regarding basic rights.

In the application of the normative UUPA, the products of Dutch colonial law have been abolished, as shown in the decisions that were "decided", such as: (1) Agrarian Law (Stbl. 1870-55) as contained in Article 51 of the Law. No. Legislation of the Netherlands Indies State Organization (Stbl. 1925-447); (2) General and Special Colonial Government Ensemble Domain Statements; (3) provisions concerning the interests of farmers, which were stipulated in the Royal Decree dated April 16, 1872 No. 29 (Stbl. 1872-117) and implementing regulations; (4) Book II of the Civil Code for all matters relating to land, water and natural resources, except for the provisions on security rights (Ramadhani, 2019).

UUPA in national life is considered very important because the relationship between the Indonesian nation and the earth is very basic and inseparable. If this relationship is not regulated by democratic principles, poverty, injustice, strife and conflict for some people in Indonesia will last and be structured for a long time. Poverty is mainly caused by the lack of public access to economic resources, namely the main access to land (Arisaputra, 2015).

UUPA In national life, it is considered very important because the relationship between the Indonesian nation and the earth is very basic and inseparable. If this relationship is not regulated by democratic principles, poverty, injustice, strife and conflict for some people in Indonesia will last and be structured for a long time. Poverty is mainly caused by the lack of public access to economic resources, namely the main access to land.

The determination of the boundaries of land ownership and control is also regulated in Article 17 paragraph 1 of the UUPA, stipulating the maximum and / or minimum area of land that can be encumbered with all the rights stipulated in Article 16 of Law no. by a family or legal entity. In the context of making society prosperous, UUPA presents a spirit of reform in the agrarian sector which at the level of implementation is known as Reform Land. The term agrarian reform in the sense of restructuring of the acquisition and use of agrarian resources has been known for a long time, although its shape and nature varies depending on the age and location of the land. land reform (Wiradi, 2000).

With the establishment of an institution that limits the maximum limit of control and ownership of agricultural land as stipulated in Article 17 paragraph (1) of the UUPA, ownership and exploitation of agricultural land that crosses borders is no longer allowed. Therefore, based on Law no. 56 PRP of 1960 concerning the Determination of Agricultural Land Areas is determined by the extent of land area that can be owned by a person.

Regarding the determination of the maximum limit on land ownership which is intended to achieve a goal, namely so that the ownership of agricultural land is more just and equitable. In addition to meeting the requirements of fiqh, there will also be an increase in 
production, because tenants who have become land owners will be more active in running their agricultural businesses (P. Sunaryo Basuki, 1999).

Ownership of agricultural land by absent persons can only be considered as such if the agricultural land is outside the district where the owner lives. This does not apply to owners living in districts adjacent to land disposal districts. Ownership of agricultural land by absent persons who is not in accordance with the principle of agricultural land is actively carried out by the owner. Apart from the land disposition that is outside the subdistrict where the owner lives, there are several causes underlying the occurrence of agricultural land ownership through absenteeism, including (Santoso, 2013):

Agricultural landowners leave the division of territory; someone who has received an inheritance from a farm located in another district; and people who buy agricultural land live outside the district adjacent to the land where the ownership is located. Furthermore, the question arises, is the implementation of the UUPA as a legal product already in accordance with the mandate of the fourth paragraph of the preamble to the 1945 Constitution above? This is reflected in the inconsistency between LoGA and sectoral laws as a legal conception, which causes conflict of law.

In its development in exploring Indonesia's natural wealth, the Government has subsequently issued many regulations related to natural wealth including; Law Number 4 of 2009 concerning Mineral and Coal Mining, Law 45 of 2009 concerning Amendments to Law Number 31 of 2004 concerning Fisheries, Law Number 32 of 2014 concerning Marine, Number 19 of 2004 concerning Stipulation of Regulations Government in lieu of Law Number 1 of 2004 concerning Amendments to Law Number 41 of 1999 concerning Forestry into Law, Law of the Republic of Indonesia Number 18 of 2004 concerning Plantations and other laws and regulations relating to the use of natural resources in Indonesia. However, unfortunately, from all of these regulations, it seems that the LoGA has not been used as a basis for its formation so that each regulation still appears to be sectoral ego (Ramadhani, 2018).

In discussing the LoGA as a legal product in the context of legal theory, it will intersect with the uses / benefits (axiology) of the law. Axiology is a branch of philosophy that studies values in general. As a basis for science, the question of axiology is to what extent has science been used? How is the relationship between how to use moral rules? How is the determination of the object analyzed on morals? How is the relationship between technical, procedural which is the operationalization of the scientific method with moral or professional standards? (Surajiyo, 2010). In discussing axiology, there are two general judgments, namely ethics and aesthetics. Therefore discussing the UUPA which is seen as a form of rule / law in relation to regulating agrarian management and utilization in Indonesia, of course, does not release the basic value as the foundation for the formation of the LoGA, namely Article 33 Paragraph (3) of the 1945 Constitution.

The basic value in general contained in the contents of Article 33 Paragraph (3) of the 1945 Constitution, namely justice for the people towards the management of agrarian resources in Indonesia with the meaning that the management and utilization of agrarian resources must be used "for the greatest prosperity for the people". And this value is also fundamental in the formation of the National Agrarian Law, namely the UUPA.

Furthermore, the basic values contained in Article 33 Paragraph (3) of the 1945 Constitution mentioned above are further elaborated by the UUPA by upholding the basic values that are held in the midst of Indonesian society, including; The principle of religiosity / paying attention to religious elements (Articles 1 and 49 of the UUPA), the principle of nationality (Articles 9, $20 \& 55$ of the UUPA), the principle of democracy (Articles $4 \& 9$ of the UUPA), the principle of equity, limitation and social justice in 
control and use of land ( Articles 7, $11 \& 17$ of UUPA), Principles of Partnership and Togetherness (Articles $11 \& 12$ of UUPA), Principles of Legal Certainty and Openness (Articles 11, $13 \& 19$ of UUPA), Principles of Use and Utilization of Land as strategic and sustainable natural resources (Article $13 \& 14$ UUPA), and the principles of just and civilized Humanity (Principle 2 of Pancasila) (Hutagalung, 2010).

According to Satjipto Rahardjo, legal theory is a continuation of efforts to study positive law (Salman \& Susanto, 2010). In this context, it seems that the legal theory of regulating agrarian management and use in Indonesia, especially land issues, has not run smoothly and is still independent. There are still many case examples which show that the basic values as described above are being corrupted.

In connection with the theory of legal certainty as mentioned above, the framework in which Muchtar Wahid deals with legal certainty of fundamental rights is determined by the functioning of 3 (three) cases, namely: a. The contents of the law consist of the objectives, systems and procedures for land registration; b. Legal structure, consisting of state security apparatus and law, and even inherent public institutions; versus legal culture, which consists of the legal awareness of society and social realities. In fact, legal certainty combined with legal certainty is often inconsistent with one another. On the one hand, it is not uncommon for legal certainty to ignore legal principles, on the other hand, it is not uncommon for law - the best principle - to become the principle of legal certainty. In practice there is a conflict between legal certainty and legal justice, so legality must take precedence. The reason is, legal truth generally emerges from the conscience of the giver of truth, so that the rule of law emerges from the concrete. Legal certainty can be interpreted as an assessment of the situation and according to the kettle and kettle. "With the provisions of the purpose of the law. Legal certainty is closely related to the feeling that a person feels safe and comfortable, because legal certainty provides certainty regarding all doubts, uncertainties and human fears. In addition, studies on legal certainty are closely related to studies of its legality (Ramadhani, 2017).

This can be seen in the blurry portrait of the world of Indonesian architecture by looking at case examples; land conflict in Tanak Awu Bandar Pesisir Mandoge (North Sumatra Province), plantation conflicts in Kampar District (Riau Province), agrarian disputes between PTPN VII and SPI in Rengas (South Sumatra Province) and a fuss over land use rights issues in Mesuji Lampung which which ends in clashes is a concrete form that the LoGA is not carried out in a straight and sustainable manner.

In general, synchronization with several laws and regulations on natural resources, particularly in the fields of water resources, forestry / planting and mining, has the right to form state power. However, in its implementation, there are major weaknesses in how to obtain land rights and the requirements and procedures for prosecuting damage caused by mining and planting.

Government policy in Law no. 32 of 2004 concerning regional government does not explicitly enforce this authority. In Article 33 paragraph 3 of the 1945 Constitution, it can be concluded that the more prosperous the people, the more systematic the basis for ownership. The organization contains the main idea, that the land needs of individuals, communities and the state require dignity or authority, strength or ability, as well as skills to work to achieve these goals. Moreover, the UUPA as an elaboration of the mandate of Article 33 paragraph (3) of the 1945 Constitution is full of social functions. inherent in it. In this regard, Tampil Anshari Siregar emphasized that; "Nothing is exempted from land rights that have no social function. Not only the land rights listed in Article 16 of the UUPA, but also those that are outside of them and which will be determined later" (Siregar, 2001). 
Even though there has been a UUPA which has become the main regulation regarding our national infrastructure, in its implementation the UUPA has not always been used as the parent of all regulations concerning land. LoGA is often not used as a reference for the formation of other laws related to the archipelago in Indonesia. Herawan Sauni argued that; The existence of these other legal provisions, regardless of whether or not they contradict the UUPA. The existence of such provisions like it or not besides the use of land for the benefit of the development sector has taken over the law had a major influence on the land tenure system in Indonesia at that time (M. Hendra Aldila, 2012).

This is also influenced by the implementation of agrarian politics which is often contradictory and even deviates from the meaning and content as well as the mandate contained in the UUPA. These deviations are often triggered by disagreements between the central and regional governments in elaborating the basic values contained in the LoGA.

Political aspects influence the transformation of the regions around the earth into attractive central government authorities in local governments. Central government is not fully subject to local government, state matters are delegated to regions by law.

The original parameters of the exercise of the state's control rights on the grounds that in accordance with Article 33 paragraph (3) of the 1945 Constitution are controlled by the state based on Article 11 paragraph (2) of Law no. Law Number 22 Year 1999 regarding Regional Government is delegated to regional government affairs that must be implemented. In statutory regulations, there is no explanation regarding the extent of the coverage of land policy parameters that fall under the authority of regencies and cities. This contradicts the UUPA where Article 2 of the UUPA states that the authority over land exists in regencies and cities considering the extent of the need. The development of agrarian law as one of the effects of the role of politics in the nation and state can be seen from the rampant issues of agrarian reform in the past few years. Starting with the issuance of MPR Decree No.IX year 2001.

During the time when landreform / landreform gained its legitimacy, which was then pushed to the National Land Agency (BPN) to immediately revise the law which had to be adjusted to the current situation, however, it is still in a long debate. Therefore, the control of land rights by the State is required within these boundaries, and this is in accordance with Maria Sriulani Sumardjono's opinion which requires that the authority to regulate the state derived from the rights of the master is limited by (Politik Hukum Agraria Indonesia Berkaitan Dengan Hak Menguasai Tanah Oleh Negara, 2011): Does not violate human rights guaranteed by the constitution; may not violate the purpose of land tenure rights by the state, as regulated in Article 2 paragraph (3) of the UUPA, and all laws and regulations regarding land must be aimed at the greatest possible welfare of the people. Henkin in Siagian (2020) says that constitutional rights in the constitution cannot be separated from the tradition of western thought or doctrine regarding individual rights.

In terms of taxation on service delivery, there are still legal problems, namely: regulated in Law Number 32 of 2004 concerning Regional Government, namely between autonomy and duties b) in the field of land tenure for the government's interest and mutual interest, the government is still hesitant to carry out its policies in accordance with the applicable provisions of this compensation in the state toll road and eastern flood channel regulations, in addition to the weak implementation of the redistribution of land directly controlled by the state.

The program of land registration and transfer of fundamental rights has shown its success. The provisions of the PP, which include the authority to supervise the implementation of land concession rights, appear to be broadly defined, but their implementation is still very weak. 
Therefore, there is a lack of facilities, funds, and personnel to encourage the passing of supervisory duties, especially on abandoned land, and land that is detached from its designated use. In addition, an issue that is no less important is related to the loss of land as regulated in Law Number 56 of 1960 which explains that land that does not exist and land that exceeds the maximum limit must be distributed to landless community groups (Ayu, 2019).

In line with community political supervision, the situation of natural resources such as; It is recorded in; Article 33 of the 1945 Constitution and UUPA, various laws and regulations were passed. Meanwhile, the levy scheme is related to the owner of human rights and human rights. land use related to water resources and forestry is equitably placed in the form of protection of basic rights and the best use of land. To make a profit.

In the mining sector, there are variations regarding regulatory ambiguity regarding the requirements and procedures for obtaining basic rights of mining companies, as well as the seriousness of these requirements. From obtaining profits in the field as a result of the presence of mining companies.

The lack of administrative and supervisory frameworks as well as differences in land arrangements are caused by past patterns of state political power when law enforcement was partially and realistically biased. From a liberal capitalist political economy. While the provisions of the regulations are in a period of reform, the pattern of government policies appears to be more democratic to provide and protect basic rights and achieve better benefits. The mismatch is mainly related to mining due to negligence and judgments of law firms; the concept of mastery of state formations on land that is ideal for the future (Erwiningsih, 2009);

First, the framework that emphasizes the relationship between the rights of the nation and the control of the state over land must be clear that the authorities, duties and obligations of the state can be placed proportionally; Second, the principles in the use of the rights of each owner of land rights (such as the principles of benefit, healthy land, morals,; third, the transfer of land affairs to local governments must be explained and in accordance with the capacity, potential and conditions of the area.

In addition, Winahyu also explained the implications that arise from the concept of managing state control over land, namely: first, so that the concept can be used as a guideline for the state in its application. national land politics law to avoid the emergence of multiple interpretations of the state's control over land; Second, to provide a political legal framework for the Indonesian nation or nation to meet the needs of land as a basis for living capital in accordance with their rights; Third, the state can carry out careful planning on its will, the allocation, use of land and the state can be maintained in the behavior of its government actions to avoid violations of the law and people's human rights (Erwiningsih, 2009).

If the right to control land by the state is properly utilized, it will provide the greatest possible happiness for the people as stated by the legal theory expressed by Jeremy Bentham through his utilitarian law philosophy, namely (gretatest happiness for the greatest number) the greatest happiness for as many people as possible. a lot.

\section{CONCLUSION}

The essence of state control is to realize the use and use of land in accordance with the rights and obligations of individuals, communities and the state to achieve the greatest prosperity and justice for the people. So in the perspective of a legal theory, the right to control land by the state must be based on three principles of legal objectives, namely covering legal certainty, justice and benefit. When this goal is achieved, it can be 
ascertained that the right to control land by the state will be able to achieve its true aims and objectives, namely the greatest possible prosperity for the people.

Apart from the conclusion, there are at least three important notes that become recommendations in this document, namely: first, there must be changes to laws and regulations which clearly and firmly state legal principles which essentially become the spirit to legitimize the authority of state control over the earth. Thus, awareness will be created between the people and the state rulers and side by side with the goal of controlling the state's politics on land proportionally so that there is no difference in interpretation or interpretation by the authorities.

Second, increasing the welfare of the people (peasants) has recently been demanded by the Olivik party, candidates for members of the Regional People's Representative Council (DPRD) and several parameter frameworks that will be immediately established and implemented are the right to use and control land, the definition of land management rights, the definition of agrarian reform related to redistribution of land on land directly controlled by the state and for the public interest.

In order to prepare for changes to the development of statutory regulations in the UUPA, synchronization with the fields of related laws and regulations, such as mining, forestry and irrigation laws, must be reactivated by the consortium of agricultural laws for the lower part of the body. The National Development Law as an independent body and reporting directly to the President for periodic academic studies of state law is required in the near future.

\section{REFERENCES}

Ahmad Nashih Luthfi, E. al. (2010). Kronik Agraria Indonesia Memperluas Imajinasi Lintas Zaman, Sektor dan Aktor. STPN Press, Sajogyo Institute dan Institute Sejarah Sosial Indonesia.

Arisaputra, M. I. (2015). Reforma Agraria Di Indonesia. Sinar Grafika.

Ayu, I. K. (2019). Problematika Pelaksanaan Pendaftaran Tanah Melalui Pendaftaran Tanah Sistematis Lengkap Di Kota Batu. Jurnal Ilmiah Hukum LEGALITY, 27(1), 27. https://doi.org/10.22219/jihl.v27i1.8956

B. Ter Haar, Bzn, Terjemahan Schiller, A. A. \& E. A. H. (1962). Adat Law In Indonesia. Bharata.

Barlowe, R. (1978). Land Resource Economics: The Economics of Real Estate. PrenticeHall Inc.

Erwiningsih, W. (2009). Pelaksanaan Pengaturan Hak Menguasai Negara atas Tanah Menurut UUD 1945. Jurnal Hukum, 16 (Edisi Khusus), 118-136.

Harsono, B. (2007). Menuju Penyempurnaan Hukum Tanah Nasional. Universitas Trisakti. Hermayulis. (1999). Disertasi; "Penerapan Hukum Pertanahan dan Pengaruhnya Terhadap Hubungan Kekerabatan Pada Sistem Kekerabatan Matrilineal Minangkabau Di Sumatera Barat".

Hidayah, N. P., \& Rahadiyan, I. (2018). Eksistensi Praktik Jual Gadai (Adol Sende) Pada Masyarakat Dusun Pentong Kelurahan Selorejo Kecamatan Pundhong Kabupaten Bantul. Jurnal Ilmiah Hukum LEGALITY, 25(2), 22. https://doi.org/10.22219/jihl.v25i2.6003

Hutagalung, A. S. (2010). "Perspektif Hukum Persoalan Agraria: Solusi Terhadap Disharmoni dan Disintergrasi Pengaturan." In Simposium Dewan Guru Besar Universitas Indonesia: Tanah Untuk Keadilan dan Kesejahteraan Rakyat (pp. 32-33). Kampus Universitas Indonesia.

Limbong, B. (2012). Hukum Agararia Nasional. Margaretha Pustaka. 
M. Hendra Aldila, E. a. (2012). Kewenangan Negara Dalam Pencabutan Hak Atas Tanah Demi Pemnbangunan Kepentingan Umum. Bengkolen Justice, 2(1), 414.

M.D, M. (2011). Politik Hukum Indonesia (Edisi Revi). Rajawali Pers.

Miriam Budiarjo. (2012). Dasar-Dasar Ilmu Politik (Edisi revi). Prima Grafika.

P. Sunaryo Basuki, et. al. (1999). Analisis dan Evaluasi Hukum Tentang Batas Pemilikan Tanah Di Daerah Perkotaan. Badan Pembinaan Hukum Nasional Departemen Kehakiman Republik Indonesia.

Politik Hukum Agraria Indonesia Berkaitan Dengan Hak Menguasai Tanah Oleh Negara. (2011). Binatangpoerba.Wordpress.Com. https://binatangpoerba.wordpress.com/2011/09/27/politik-hukum-agraria-indonesiaberkaitan-dengan-hak-menguasai-tanah-oleh-negara/

Ramadhani, R. (2017). Jaminan Kepastian Hukum Yang Terkandung Dalam Sertipikat Hak Atas Tanah. De Lega Lata: Jurnal Imu Hukum, 2(1), 139-157. https://doi.org/10.31219/osf.io/6tzes

Ramadhani, R. (2018a). Beda Nama dan Jaminan Kepastian Hukum Sertifikat Hak Atas Tanah (I. Nainggolan \& Fajaruddin (Eds.)). CV. Pustaka Prima.

Ramadhani, R. (2018b). Buku Ajar: Hukum Agraria (Suatu Pengantar). CV. Pustaka Prima.

Ramadhani, R. (2019). Dasar-Dasar Hukum Agraria. CV. Pustaka Prima.

Salman, O., \& Susanto, A. F. (2010). Teori Hukum; Mengingat, Mengumpulkan, dan Membuka Kembali. PT. Refika Aditama.

Santoso, U. (2013). Hukum Agraria Kajian Komprehensif. Kencana.

Siagian, A. H. (2020). Constitutional Complaint as Strengthening Constitutionalism in Indonesia. Randwick International of Social Science Journal, 1(3), 486-498. https://doi.org/10.47175/rissj.v1i3.102

Siregar, T. A. (2001). Undang-Undang Pokok Agraria dalam Bagan. KSHM (Kelompok Studi Hukum dan Masyarakat), FH USU.

Soehino. (1998). Ilmu Negara. Liberty.

Soejono, et. al. (1998). Prosedur Pendaftaran Tanah Tentang Hak Milik Sewa Guna dan Hak Guna Bangunan. Rineka Cipta.

Soeroso, R. (1996). Pengantar Ilmu Hukum. Sinar Grafika.

Surajiyo. (2010). Filsafat Ilmu. PT. Bumi Aksara.

Tristanto, W. Y. (2019). Harmonisasi Regulasi Kepemilikan Tanah Pertanian Secara Absentee Bagi Pegawai Negeri Dalam Program Landreform. Jurnal Ilmiah Hukum LEGALITY, 26(2), 281. https://doi.org/10.22219/jihl.v26i2.7801

Wiradi, G. (2000). Reforma Agraria: Perjalanan Yang Belum Berakhir. Insist Pers, KPA dan Pustaka Pelajar.

Yamin, M. (1971). Naskah Persiapan Undang-Undang Dasar 1945. Penerbit Siguntang.

Zakie, M. (2017). Konflik Agraria Yang Tak Pernah Reda. Jurnal Ilmiah Hukum LEGALITY, 24(1), 40. https://doi.org/10.22219/jihl.v24i1.4256 